\title{
Klasyczne podejścia do interpretacji praktyk poznawczych podmiotu w polityce: od czasów antycznych do średniowiecza
}

\section{Classical Approaches to Interpretation of Cognitive Practice in Politics: From Antiquity to the Middle Ages}

\begin{abstract}
The importance of research on theoretical understanding of the problem of cognitive practices in political science and traditional explanations of cognitive practices as a basic mechanism for explaining policy are presented in the article. The ways cognition was understood by thinkers in antiquity and the Middle Ages are explained. The article also presents the understanding of political institutions and processes and the place of a person as the primary subject of knowledge.
\end{abstract}

Keywords: knowledge, political entity, the state, freedom, bigotry

Słowa kluczowe: proces poznawczy, podmiot polityczny, państwo, wolność, fanatyzm

Problem organizacji praktyk poznawczych podmiotu, logiki ich formowania oraz funkcjonowania można uważać za jeden z podstawowych w metodologii nauki o polityce, ponieważ stanowi on bazę polityki, wytwarzając jej najważniejsze procesualne właściwości.

Pytanie o stosunek bytu społecznego do świadomości, zwłaszcza w jego klasycznych interpretacjach, nie może być redukowane do problemu korelacji psychicznych oraz fizjologicznych procesów lub aksjomatycznego utrwalenia szeregu klasyczno-słownikowych znaczeń podmiotu politycznego.

Rozważania teoretyczne nad problemem organizacji praktyk poznawczych w nauce o polityce są podobne do piramidy, w której na najniższych poziomach znajduje się szerokie spektrum różnych koncepcji, zmysłowych obrazów - tego wszystkiego, co otrzymuje swoje oznaczenie teoretyczne przez socjalizację polityczną, poziom świadomości politycznej, pojęcie politycznej podmiotowości itp. Wygląda na to, że wszystko co powtarzalne porządkuje pamięć według typów, klas w taki sposób pojawia się nowy stopień w poznaniu oraz nowa wiedza o polityce. 
Celem artykułu jest opis klasycznych podejść do interpretacji praktyk poznawczych. Teoretyczne rozważania nad danym problemem warto rozpocząć od czasów antycznych. Specyfika politycznej myśli starożytności polega na wyznaczonej w jej granicach charakterystyce świadomości mitologicznej, tzn. na wyrazistej polaryzacji „swój-cudzy”, połączonej z wyrażonym pragnieniem porządku w zgodzie z zasadami rozumu.

Heraklit zaznaczył, że ulotność, zmienność, znikanie oraz pojawianie się dużej ilości szczegółów, w poznaniu których służą zmysły tworzy swoisty byt (Logos) ${ }^{1}$. Dialektyka Heraklita przewiduje połączenie przeciwieństw, ich ruchu. Ten ostatni, filozof uważa za istotny. „Dwa razy do tej samej rzeki nie wejdziesz”, pisał zaznaczając, że już zupełnie inna woda obmywa tego, kto się kąpie w tej rzece po raz drugi. Analogiczny aforyzm Solomona „Wszystko mija” ukazuje moment przejścia tego, co jeszcze jest, w to, czego już nie ma, co już minęło.

Według Platona uczucie - to proces: podmiot odtwarza ruch obiektu. Filozof nie utożsamia jednak wiedzy z uczuciem. Uważa, że władcą wiedzy jest dusza, którą warto rozumieć jako świadomość. „Jest zrozumiałe to, że dusza (świadomość) ma wiedzę o ogólnym, istotnym, potrzebnym, że ta wiedza mieści się w pomysłach (pojęciach, kategoriach): „piękne” i „brzydkie”, „dobro” i „zło”, ,jakość” i „ilość”, „stosunek”, „przyczyna”, „skutek” itd. Ale jest też zrozumiałe to, że za pomocą zmysłów można postrzegać kolor, formę, dźwięk, słone, kwaśne itd., natomiast dobro, jakość, przyczynę już nie... Dla postrzegania ogólnych pomysłów w duszy nie ma pomocników”2. Wiedza o przedmiocie jest bazowana na osiągnięciu jego istoty $^{3}$. Na przykład pojęcie państwa zawiera formy idealnych konstrukcji oraz ich przeciwieństw, które ograniczają wolność sa mowyrażenia człowieka. Świat dookoła nas, zgodnie z filozofią Platona, przewiduje dualizm - ilość przedmiotów, które mamy możliwość postrzegać, uzupełnia się ilością ich praobrazów, ich idealnych modeli. Pierwszy świat jest nietrwały, drugi - wieczny. Tylko świat obrazów, świat pomysłów jest harmonijny, w przeciwieństwie do świata przedmiotów, które mamy możliwość postrzegać. „Jednak świat zgodny z myślą” i „świat zgodny z prawdą" to tylko dwa poziomy wiedzy o świecie. Świat jest jeden i zawiera w sobie swoją przyczynę oraz swoją istotę"4. Te dwa światy Platona są obiektywnie istniejące. Pierwszy z nich jest wyjaśnieniem, przyczyną oraz istotą innego świata, który można rozpatrywać jako wtórny w stosunku do świata pomysłów, nieprze-

F.T. Mykhaylov, Zahadka chelovecheskoho Ya, http://lib.sibnet.ru/book/2776, odczyt z 28.01.2014.

2 Ibidem.

3 Aristotel', Polityka, Kyiv 2000, s. 111.

4 F.T. Mykhaylov, op. cit. 
mijających praobrazów wszystkich zjawisk i przedmiotów. Pomysły, tzn. obiektywna strona naszej wiedzy o przedmiotach, odtwarza się w ich realnym bycie.

Normatywną teorię państwa, skonstruowaną przez Platona na podstawie jego postrzegania sprawiedliwości oraz cnót, wiedzy jako dobra, warto rozumieć jako jeden z głównych znaków epoki. Już na wstępie należy zrezygnować z oznaczenia jego (Platona) rozumienia państwa jako utopijnego, ponieważ utopia przewiduje możliwość zestawienia z pojęciami, które są już opracowane - o utopijności można mówić tylko w warunkach racjonalnie zbudowanych pojęć. Platon z koleji podejmuje próby oznaczenia tych pojęć.

Dla Platona w zestawieniu „człowiek-państwo” podstawowym było ostatnie - ono dominowało nad człowiekiem, rozpraszało go we własnej doskonałości, przetwarzając w mechanizm, którego aktywność była gwarantem prawidłowego funkcjonowania państwa w ogóle - ponieważ my tworzymy państwo, nie dbając o to, żeby któraś z warstw społecznych była wyjątkowo szczęśliwa - na odwrót, szczęśliwe ma być państwo 5 . Celem jego istnienia jest szczęście ogółu, a nie poszczególnych jednostek. Taka hierarchia przewiduje stratyfikację w wymiarze społecznym zgodnie z własnymi możliwościami. Kryterium takiej stratyfikacji jest rozum, który wskazuje człowieka - jego status w państwie, na to, co powinien zrobić dla dobra państwa: każdemu z obywateli trzeba zlecać taką działalność, do której jest on przydatny, żeby zajmując się sprawą, która mu pasuje działał dla dobra ogółu ${ }^{6}$.

Oczywiście państwo zbudowane rozumnie oraz hierarchicznie przewiduje szczególną formę panowania-kierowania - „dzięki najmniejszej cząstce swojej ludności, cząstce, która stoi na czele państwa i nią kieruje oraz dzięki wiedzy, którą ta cząstka posiada, całe państwo, zbudowane zgodnie z naturą, byłoby mądre" "Taki elitaryzm jest powołany do zabezpieczenia prawidłowego, rozumnego istnienia państwa, ponieważ tylko ci, którzy są mądrzy, mogą być gwarancją sprawiedliwości, którą powinno być wypełnione całe państwo, wszystkie aspekty jego bytu.

Otóż zgodnie z interpretacją sensu państwa według Platona, człowiek powinien skupiać się na podkreślaniu własnych możliwości, skierowanych na dobrobyt państwa. W państwie nie ma miejsca na legalno-legitymistyczne istnienie osób myślących inaczej.

Arystoteles był zwolennikiem innego założenia. Chcąc pokonać idealizm Platona wychodził z założenia, że forma, nie będąc wewnętrzną właściwością materii,

Platon, Derzhava, Kyiv 2000, s. 107.

Ibidem, s. 111.

7 Ibidem, s. 117. 
jest istotą, która wyraża jej pasywność. Świat znowu się podwoił - każda rzecz otrzymuje podwójną naturę, stając się materią. Przedmioty świata obiektywnego łączą w sobie dwa początki - ogólny (forma) oraz idywidualny (materia, z której forma tworzy przedmiot). Jednak tutaj jeszcze nie ma dialektycznej jedności przeciwieństw - „forma po prostu obdarza rzeczy zmysłowe wiecznością” - w taki sposób zgodnie ze słowami Arystotelesa o „ideach” Platona, można scharakteryzować naukę o „formach".

Zgodnie ze stwierdzeniem Arystotelesa państwo - to jedność, stworzona dla osiągnięcia szczęścia9. Jest ona niemożliwa bez stosunku podporządkowania, bez gospodarza i niewolnika - pierwszy dzięki swoim możliwościom umysłowym ma zdolność do przewidywania, dlatego on jest istotą, która panuje; drugi jest osobą podporządkowaną i niewolnikiem, ponieważ może wykonywać wyłącznie pracę fizyczną. Zarówno dla pana, jak i niewolnika jest to korzystne ${ }^{10}$.

Natura państwa jest uwarunkowana jego pochodzeniem. Zdaniem Arystotelesa bierze ono swój początek z rodziny, z której utworzyły się większe skupiska ludzi, a z nich państwo ${ }^{11}$. Stąd wynika znana teza Arystotelesa o tym, że człowiek jest istotą polityczną.

Jednocześnie u Arystotelesa spotykamy się z interesującym problemem niewolnika. Niewolnik to ten, który naturalnie należy nie do sobie, lecz przynależny jest innemu człowiekowi - chociaż jest człowiekiem, to jednak ze swojej natury jest niewolnikiem. Człowiek należy do innego, staje się własnością; istniejąc osobno, jest zasobem ${ }^{12}$. Panujący wie, co trzeba robić, a podległy ma fizyczny zapał do tworzenia: absolutny tandem teologiczny. Państwo przewiduje podobny arystotelesowski podział - ten, który panuje, jest kierownikiem. Ci wszyscy, którzy różnią się od innych ludzi w taki sposób, jak dusza różni się od ciała, a człowiek od zwierzęcia (chodzi o tych, których działalność jest powiązana z pracą fizyczną) - tacy ludzie ze swojej natury są niewolnikami; zarówno dla nich, jak i dla innych istot żywych, najlepszym sposobem istnienia jest bycie czyjąś własnością. Niewolnik ze swojej natury to ten, który może być własnością innego ${ }^{13}$. Niewolnik jest narzędziem produkowania. Kiedy niewolnik jest własnością, to jest on niewolnikiem nie tylko gospodarza, ale też niewolnikiem w sensie absolutnym. Ten, kto jest gospodarzem w sensie absolutnym, nie jest gospodarzem (niewolnika), tylko jego

\footnotetext{
8 F.T. Mykhaylov, op. cit.

Aristotel', op. cit, s. 115.

Ibidem, s. 15-16.

Ibidem, s. 16.

Ibidem, s. 19.

13 Ibidem, s. 20.
} 
władcą $^{14}$. Z reguły panowanie i podporządkowanie są korzystne, ponieważ ułatwiają ludziom życie, są zgodne z zasadami sprawiedliwości. Władza panującego ogranicza człowieka, i to powinno być dla niego korzystne, ponieważ odpowiada to jego naturalnym ograniczeniom.

Osobno trzeba zastanowić się nad pojęciem obywatelstwa. Błędnie byłoby rozpatrywanie stosunków „obywatel - nieobywatel” w sposób uproszczony - „nie bierzemy pod uwagę tych obywateli, którzy są za nich uważani ze względu na szczególne zasługi dla państwa. Nawet miejsce zamieszkania nie jest $\mathrm{w}$ stanie zrobić z człowieka obywatela” ${ }^{15}$, „za obywateli będziemy uważać tych, którzy biorą udział w sądzeniu i zgromadzeniach ludowych"16. Cnotliwość obywateli jest uwarunkowana funkcjonawaniem państwa, ona dopuszcza między nimi różnice, jednak tylko takie, które nie wychodzą za granice funkcjonawania i natury samego państwa. Cnotliwość dobrego obywatela polega na tym, żeby potrafić umiejętnie wydawać rozkazy oraz w należyty sposób podporządkowywać się ${ }^{17}$. Filozof uważał, że obywatele nie mogą istnieć osobno od spraw państwa - „zjednoczenie jest pewną więzią, dlatego stwierdzenie, że obywatele nie mają potrzeby więzi jest sprzeczne ze zdrowym rozsądkiem. Zrozumiałym jest też to, że obywatele powinni podtrzymywać więzi we wspólnym dla nich miejscu" ${ }^{18}$. Zjednoczenie obywateli w sprawach państwowych jest przewidziane potrzebą komunikowania się między nimi.

W tym kontekście pojawia się zjawisko ostracyzmu. Etymologicznie oznacza „kawałek glinianego dzbana”. Na nim obywatele pisali imię tego, kogo chcieli wypędzić z polis. Ostracyzm był środkiem prewencyjnym, wypędzano tylko tych, którzy mogli nieść potencjalne zagrożenie. Arystoteles uważał, że ostracyzm jest „uniwersalny w zastosowaniu w każdym ustroju państwowym”19. Jest on swoistym środkiem zapobiegawczym, powołanym do niwelowania zjawisk negatywnych, które są sprzeczne z logiką istnienia państwa przez wpływ tych ludzi, którzy nie postępują zgodnie z zasadami rozumu - „nic nie przeszkadza tym, którzy kierują państwem działać zgodnie z interesami społeczeństwa, używając ostracyzmu wtedy, kiedy jest to korzystne dla ich osobistej władzy i bogactwa państwa"20.

Celem stosowania takich środków był dobrobyt obywateli - „w taki sposób z naturalnego stanu państwa niewątpliwie wynika to, że będzie ono mieć najlep-

\footnotetext{
14 T. Akvins'kyy, op. cit., s. 45.

15 Aristotel', op. cit., s. 67.

16 Ibidem.

17 Ibidem, s. 71.

18 T. Akvins'kyy, op. cit., s. 105.

19 Aristotel', op. cit, s. 89.

20 Ibidem.
} 
szy ustrój państwowy w tym wypadku, kiedy w jego składzie będą „obywatele stanu średniego" 21.

W taki sposób u Arystotelesa nauka o formach nabywa politycznego znaczenia i pokazuje mechanizmy praktyk poznawczych podmiotu w polityce, mechanizmy ich spełnienia oraz ograniczenia.

Wejście chrześcijaństwa na arenę światowej myśli politycznej w sposób paradoksalny inicjowało przesuwanie akcentów na jedną z zasad, które są do niego przeciwne - non serviam, „nie będę służyć”. Na miejscu rozumu staje wiara w nadrozum: Bożą „prawdę”.

Pytanie o specyfikę praktyk poznawczych podmiotu w tym czasie stało się wyraziste. "Ani w niebie, ani na ziemi” nie ma ogólnego, lecz tylko pojedyncze, szczególne, niepowtarzalne rzeczy. Tylko w ludzkiej świadomości jest ogólne imię, które ludzie nadają kompletowi rzeczy pojedynczych ${ }^{22}$.

"Na początku było Słowo a Słowo było u Boga, i Bogiem było Słowo”23 - główne uzasadnienie chrześcijaństwa, które obok prawa wprowadzało pojęcie prawdy danej od Boga. Faktycznie miało miejsce załamanie między dwoma światami Bóg transcedentalny, Absolut, Twórca wszystkiego żywego oraz świat materialny, w granicach którego istnieją przepisy i którego cechy ogólne nie są sprzeczne z wiarą. Działanie człowieka jest skierowane na prawdę, która jest pozbawiona obciążenia funkcjonalnego. Hierarchiczność jest tutaj sakralizowana - „Ten, który przychodzi z góry, Ten jest nad wszystkimi”" ${ }^{24}$. Faktycznie jedynym kryterium, które wyróżnia specyfikę praktyk poznawczych, a także ich wymiaru politycznego, staje się wiara - „Przyszedłem na ten świat, aby przeprowadzić sąd, aby ci, którzy nie widzą, przejrzeli, a ci, którzy widzą stali się niewidomymi”"25. Oczywiście chodzi tutaj o ślepotę duchową.

Jednocześnie fenomen średniowiecznej inkwizycji stał się formą prześladowań tych podmiotów politycznych, których poznawcza aktywność wy różniała się jako niezgodna z wiarą. Takie błędy okazały się niebezpośrednim tworem chrześcijaństwa - niebezpośrednim, ponieważ nie były one przewidziane doktryną, lecz stały się rezultatem tego, że chrześcijaństwo zdobyło status nie tylko religii panującej, ale także ideologii. Kościół bardzo mocno wplótł się w kreacje instytucjonalno-polityczne. Pojawienie się inkwizycji nie dziwi, ponieważ człowiek jeszcze nie był gotowy do instytucjonalnego umocnienia wolności oraz pluralizmu. Twierdzenie

\footnotetext{
${ }^{21}$ Ibidem, s. 115.

22 F.T. Mykhaylov, op.cit.

23 Novyy Zavit, Kyiv 2003, s. 114.

24 Ibidem, s. 117.

25 Ibidem, s. 129.
} 
że wiara stoi wyżej od przepisów zniekształciło się, ponieważ wiara jako taka nie ma wymiaru praktycznego.

Co dotyczy relacji władzy i jednostki precyzyjnie ukazuje cytat: „Każdy człowiek niech się poddaje władzom zwierzchnim; bo nie ma władzy, jak tylko od Boga, a te, które są, przez Boga są ustanowione. Przeto kto się przeciwstawia władzy, przeciwstawia się Bożemu postanowieniu; a ci, którzy się przeciwstawiają, sami na siebie potępienie ściągają. Rządzący bowiem nie są postrachem dla tych, którzy pełnią dobre uczynki, lecz dla tych, którzy pełnią złe. Chcesz się nie bać władzy? Czyń dobrze, a będziesz miał od niej pochwałę" ${ }^{26}$. W ten sposób sankcjonuje się istnienie władzy i funkcjonowanie chrześcijaństwa w granicach państwa, bez wewnętrznych sporów.

Znany teolog Étienne Gilson słusznie zaznaczył, że postępowanie „nie tak, jak wszyscy”, w końcu męczy ${ }^{27}$. Religia staje się bezapelacyjnym wyznacznikiem średniowiecznego społeczeństwa - „człowiek, wychowany w łonie kościoła, w którym kazania, zakazy, rozkazy pełnią główną rolę, będzie w sposób naturalny skłaniać się do rozumienia społecznego jako systemu ograniczeń" ${ }^{28}$. Zarówno specyfika praktyk poznawczych w ogóle, jak i jej wymiar polityczny, nabywają wyrazistego znaczenia przez wiarę. Wszystko, co znajduje się poza jej granicami automatycznie staje się błędne. Granica dla określenia specyfiki praktyk poznawczych jest dość wyraźna.

Łączenie wiary z politycznymi instytucjami w średniowieczu stało się przyczyną wielu problemów, m.in. fanatyzmu. Nie jest on synonimem mitologicznego podziału „swój-cudzy”. Fanatyzm ma cechy polityczne i instytucjonalne: Święta Inkwizycja. To także swoisty porządek, rozpisywanie ludzkiego życia w sposób ortodoksyjny - bezwzględnym układem założeń, których teoretyczna niezaprzeczalność bazuje na zasadach wiary. Jest to nie tylko nieprzyjęcie innej opinii, ale też brak tolerancji dla niej - myślenie w inny sposób nie ma prawa bytu, bo jest ono obraźliwe $^{29}$. Średniowieczny fanatyk posiadał potrzebne mechanizmy, by jego podejrzenia otrzymały bardziej radykalne wcielenie w granicach represyjnych instytucji. Człowiek, opętany manią prześladowania, który czuje, że jest otoczony wrogami - jest istotą bardzo niebezpieczną, staje się prześladowcą, prześladuje,

\footnotetext{
26 Ibidem, s. 199.

27 Э. Zhyl'son, Fylosof y teolohyya, http://filosof.historic.ru/books/item/f00/s00/z0000169/, odczyt z 12.08.2012.

28 Ibidem.

29 N.A. Berdyaev, O fanatyzme, ortodoksyy y ystyne, http://www.vehi.net/berdyaev/fanatizm. html, odczyt z 7.12.2013.
} 
a nie jego prześladują"30. Inną cechą fanatycznego postrzegania świata jest perfekcjonizm, przejawiający się w nieprzerwanej walce fanatyka o wytępienie wszelkiej sprzeczności.

Gwałt i okrucieństwo dla fanatyka faktycznie nie są czymś nie do przyjęcia są one dopuszczalnymi kryteriami uciskania innych - fanatyzm bierze początek od religii, ale łatwo przechodzi do wymiaru politycznego ${ }^{31}$. Fanatyzm nie ma nic wspólnego z wiarą i religią - wiara ze swojej natury jest pozytywna i nie może prowokować do nienawiści. Mikołaj Bierdiajew zaznaczał że „w swojej istocie fanatyzm zawsze miał charakter społeczny. Człowiek nie może być fanatykiem, jeśli jest on postawiony przed Bogiem. Staje się fanatykiem wtedy, kiedy jest postawiony przed innymi ludźmi" ${ }^{32}$.

Przeprowadzona analiza ukazuje ważność badania praktyk poznawczych podmiotu jako czynnika rozumienia polityki. Akcent na epokę antyczną oraz średniowieczną pozwala na lepsze ich zrozumienie także w czasach późniejszych.

\footnotetext{
30 Ibidem.

31 Ibidem.

32 Ibidem.
} 